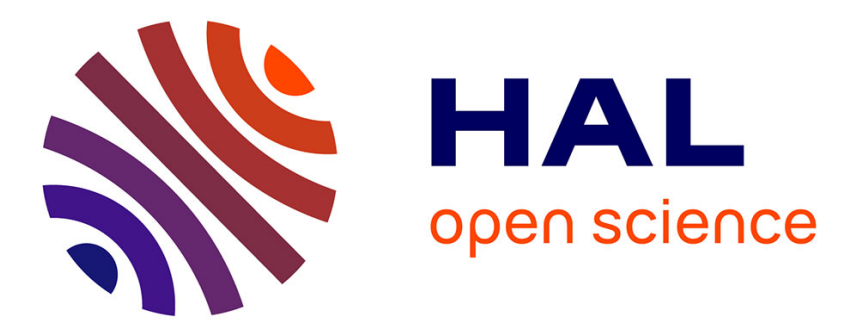

\title{
Stress corrosion of GRP tensile strength members in optical fibre cables
}

\author{
R. Leetham, S. Kukureka
}

\section{To cite this version:}

R. Leetham, S. Kukureka. Stress corrosion of GRP tensile strength members in optical fibre cables. Journal de Physique IV Proceedings, 1993, 03 (C7), pp.C7-1665-C7-1668. 10.1051/jp4:19937261 . jpa-00251901

\section{HAL Id: jpa-00251901 https://hal.science/jpa-00251901}

Submitted on 1 Jan 1993

HAL is a multi-disciplinary open access archive for the deposit and dissemination of scientific research documents, whether they are published or not. The documents may come from teaching and research institutions in France or abroad, or from public or private research centers.
L'archive ouverte pluridisciplinaire HAL, est destinée au dépôt et à la diffusion de documents scientifiques de niveau recherche, publiés ou non, émanant des établissements d'enseignement et de recherche français ou étrangers, des laboratoires publics ou privés. 


\title{
Stress corrosion of GRP tensile strength members in optical fibre cables
}

\author{
R. LEETHAM and S.N. KUKUREKA \\ The University of Birmingham, School of Metallurgy and Materials, Edgbaston, Birmingham, B15 2TT, \\ U.K.
}

\begin{abstract}
Pultruded glass fibre reinforced plastics (or GRP) rod is being increasingly used in the area of cable design, used for strength members in optical fibre cables. The possibility of failure by the process of stress corrosion has resulted in the need to determine the reliability of the dielectric cables when in service. The viability of life predictions being made from the study of stress corrosion fracture surfaces is investigated. The production of static fatigue data for composite materials is needed to enable any accurate predictions to be made.
\end{abstract}

\section{INTRODUCTION}

A greater demand for improvement in the speed and efficiency of the telecommunication systems around the world, has resulted in the replacement of the existing copper signal-carrier systems with optical fibres [1]. In countries where there is a large number of electrical storms, non-conducting communication cables are seen as desirable. This is one of the reasons why the development of non-conducting (or dielectric) cables has been encouraged. Dielectric cables are also desirable in high voltage areas, e.g. along railway lines or when the cable is in close proximity to the power transmission lines [2][3]. For the optical fibres to perform as effectively as possible for the duration of their life there is a need for the cable to contain a strengthening component. Even small amounts of damage can significantly impair the performance of optical fibres [4]. The cable strength member provides the properties necessary for adequate protection of the optical fibres and to provide the cable with the mechanical properties essential for ease of installation and the continuation of optimum performance when in service.

\subsection{GRP as a cable strength member}

The material most commonly used for the cable strength member is steel, in solid or braided forms. For dielectric cables an alternative material is necessary. Glass fibre reinforced plastics is on of the alternative materials that can be used [4][5][6]. In order to provide the necessary mechanical properties, the GRP contains a high volume fraction of reinforcing fibres, in the region of $70 \%$. The high strengths required from the cable strength member are attained by using GRP with continuous, unidirectional glass fibres which run the length of the cable. The GRP rod used for the strength member is manufactured by the pultrusion process.

\subsection{Stress Corrosion of GRP}

The use of GRP in an application where the major stress acting on the material is a constant, unvarying tensile stress is unusual. Cables generally have a specified lifetime of 25 years although lifetimes as high as 40 years can be specified [5]. In order to guarantee that the cable will survive for this length of time the reliability of the GRP as a cable strength member requires investigation. It is well documented that glass suffers from the problems of failure by stress corrosion [7][8][9][10]: failure by slow crack growth caused by the application of stress in the presence of an aggressive environment. Investigations into the effects of stress combined with the presence of an aggressive environment on GRP have also found that GRP suffers 
from stress corrosion failures [11][12][13]. The need for investigation into the reliability of GRP as a cable strength member has been further emphasised by the discovery of premature failures in GRP radio antennae guy ropes [3][14]. This particular application can be compared with that of the cable strength member because the GRP guy ropes were also sustaining continuous tensile loads for long periods of time. Failures were observed in the guy ropes after only a few years of service at loads that were a fraction of the predicted breaking loads. The fracture surfaces were found to be uncharacteristically smooth and planar. Short term GRP failures tend to have a fibrous or brush-like appearance. The smooth fracture surface was thought to be the product of a tensile stress in the presence of an aggressive environment: a stress corrosion failure.

\section{FRACTOGRAPHY AND LIFE PREDICTION}

The fracture surface of a failed glass fibres shows three characteristic regions: 1 the mirror zone, a smooth planar surface with a mirror-like finish; 2 the mist region, an area where small radial ridges can be seen; 3 the hackle, a region showing larger radial ridges [15][16][17]. The fracture surface is evident in specimens tested in air and those that have undergone stress corrosion. It has been suggested that these surface markings, the mirror zone in particular, may be of use in finding the time to failure of the glass fibre [18]. This may ultimately lead to prediction of the lifetime of the GRP strength member.

\subsection{Mirror Zone Measurement}

The origin of the possibility for life prediction lies in an empirical relationship that was first put forward by Terao [19]. This relationship relates the mirror zone radius, $M_{r}$ to the fracture stress, $\sigma_{f}^{*}$ as follows:

$$
\sigma_{\mathrm{f}}^{*} \mathrm{M}_{\mathrm{r}}^{1 / 2}=\text { Constant }
$$

Work by Levengood [15] also indicated that this relationship was possible. More recent work by Jaras et al [20] established the value of the constant to be $1.46 \mathrm{MNm}^{-3 / 2}$ for E-glass fibres through the examination and measurement of the mirror zones of fractured fibres.

\subsection{Crack Propagation}

Continuing the investigation into the possibility of life prediction leads towards the study of crack propagation in glass fibre reinforced plastics. The crack velocity, $v$ has been shown to vary with $K_{l}$, the stress intensity, by a simple power law as follows [13][12]:

$$
\mathrm{v}=\frac{\mathrm{da}}{\mathrm{dt}}=\mathrm{AK}_{\mathrm{I}}^{\mathrm{n}}
$$

where $\mathrm{A}$ and $\mathrm{n}$ are material constants ( $\mathrm{n}$ is also refered to as the stress corrosion factor). In order to determine the values of the material constants plots of $\log v$ versus $\log \mathrm{K}_{\mathrm{I}}$ can be constructed. In the case of obtaining life prediction data form actual components, such as the strength member, it is difficult to obtain values for the crack velocity and the stress intensity. This is where the importance of fractography is realised. However, for life predictions to be made from fractographical analysis of a composite then it is necessary to find a method of determining both the stress intensity at the crack tip and the crack velocity by fractographical means.

\subsection{Fractographical Determination of $K_{I}$}

Price and Hull [12] stated that the crack growth rate was dependent on the applied stress and the environment. If the dependence of the crack growth on the stress intensity at the crack tip was known then the lifetime of a GRP component exposed to a particular environment could be predicted. A knowledge of the stress field at the crack tip would therefore be advantageous. Sih et al [21] found the principal stresses around the crack tip. A simplified equation for $\sigma_{y}$ can be used to show the stress perpendicular to the fracture plane in a stress corrosion failure |18|: 


$$
\sigma_{y}=\frac{K_{I}}{(2 \pi r)^{1 / 2}}
$$

In this relationship $r$, the distance from the crack tip must be give a finite value as $\sigma_{y}$ tends to infinity as $r$ tends to zero. The stress perpendicular to the fracture plane can be compared to the fracture stress, $\sigma_{\mathrm{f}}{ }^{*}$, obtained from measurement of the mirror zone on the fracture surface of a failed fibre, as follows [18]:

$$
K_{I}=(2 \pi r)^{1 / 2} \cdot \text { constant. } \frac{1}{M_{r}^{1 / 2}}
$$

Using Equation 4 it is possible to obtain the crack tip stress through fractographical analysis of failed fibres.

\subsection{Fractographical Determination of $v$}

To determine the crack velocity from the measurements taken from a fibre fracture surface, relevant static fatigue data is needed [18]. The static fatigue data relates the stress applied to a fibre to its lifetime in a given environment. Metcalfe and Schmitz [9][10] have done a large amount of work on the static fatigue of glass fibres including E-glass, the most commonly used reinforcing fibre. First of all the term static fatigue should be explained. Static fatigue is associated with brittle materials and particularly with glass. It is where the application of a constant, and of ten small, load to a material causes a gradual reduction in the material strength over a period of time [9][10]. This reduction in strength can be accelerated by the presence of an aggressive environment such as a mineral acid. Metcalfe and Schmitz undertook extensive testing of E-glass fibres including static fatigue testing [9]. Curves of applied stress/tensile reference versus $\log$ (time to failure) were plotted. The fibre fracture stress, $\sigma_{f}{ }^{*}$, calculated from the $M_{r}$ measurements together with a reference breaking stress obtained from tensile failure of a specimen tested in air could be used to obtain the time to failure of a fibre tested in $\mathrm{HCl}$. The velocity could then be calculated assuming that the time taken for a crack to propagate through the fibre and the surrounding resin is the same as that for the bare fibre [18].

\subsection{Life prediction}

Once the values for the stress intensity and the crack velocity have been found plots of $\log \mathrm{v}$ versus $\mathrm{K}_{\mathrm{I}}$ can be constructed. It has been suggested that the time to failure for the composite can be determined by the integration of the $\mathrm{K}, \mathrm{V}$ diagram. Before this can be achieved it is necessary to obtain accurate measurements of the velocity and the stress intensity.

\section{EXPERIMENTAL TECHNIQUES}

Pultruded GRP rod was subjected to dead-weight loading in the presence of $1 \mathrm{M} \mathrm{HCl}$. The specimen was tested in a four-point bend configuration and was subjected to a load of approximately $20 \mathrm{~N}$. The GRP rod was $10 \mathrm{~mm}$ in diameter with a slot, $2.8 \times 3.8 \mathrm{~mm}$ in size, running the length of the rod. The specimen was tested with the slot on the upper most surface of the rod. A notch was also introduced to the specimen which was of significant size, arresting approximately $2 \mathrm{~mm}$ from the bottom of the slot. The specimen remained under load until failure of the specimen occurred. Failure was defined as the point when the specimen could no longer sustain a load. The fracture surface of the failed specimen was then examined under a scanning electron microscope (SEM). Particular attention was paid to the size of the observed mirror zones.

\section{RESULTS AND DISCUSSION}

Using the equations stated above and measurements made from micrographs of the specimen fracture surfaces, the fracture stress, the stress intensity and the crack velocity were calculated. The values obtained can be seen in Table 1. The values for the crack velocity agree well with those calculated by Price [18] for an E-glass/polyester composite. As can be clearly be seen from the table the errors involved in the calculations are significant. Despite the large errors involved, the results obtained are promising regarding the viability of obtaining information such as the crack velocity from the study of the fracture surface of 
failed specimens of GRP. Large errors are to be expected since the values were obtained using data

\begin{tabular}{|c|c|c|c|c|c|}
\hline Fibre & $\begin{array}{c}\text { Diameter } \\
\boldsymbol{\mu} \mathbf{~ m}\end{array}$ & $\begin{array}{c}\mathbf{M r} \\
\boldsymbol{\mu} \mathbf{m}\end{array}$ & $\begin{array}{c}\text { of } \\
\mathbf{M P a}\end{array}$ & $\begin{array}{c}\text { KI } \\
\mathbf{M N m - 3 / 2}\end{array}$ & $\begin{array}{c}\mathbf{v} \\
\mathbf{1 0} \mathbf{- 9} \mathbf{m s - 1}\end{array}$ \\
\hline A & $17.4 \pm 0.2$ & $7.1 \pm 0.2$ & $574 \pm 8$ & $22 \pm 81$ & $1 \pm 2$ \\
B & $14.5 \pm 0.2$ & $4.9 \pm 0.2$ & $660 \pm 14$ & $26 \pm 13$ & $36 \pm 43$ \\
C & $16 \pm 0.2$ & $8.3 \pm 0.2$ & $503 \pm 0.6$ & $20 \pm 10$ & $5 \pm 13$ \\
D & $15.1 \pm 0.2$ & $5.2 \pm 0.2$ & $635 \pm 6$ & $25 \pm 13$ & $67 \pm 119$ \\
E & $13.4 \pm 0.2$ & $5.4 \pm 0.2$ & $635 \pm 6$ & $25 \pm 13$ & $59 \pm 105$ \\
\hline
\end{tabular}

Table 1 Values obtained from measurements of the mirror zone radii made from the fracture surface of the pultr subjected to dead-weight loading in the presence of $1 \mathrm{M} \mathrm{HCl}$.

collected from the testing of bare E-glass fibres. The use of the E-glass fibre static fatigue data was based on the assumption that matrix cracking is instantaneous upon failure of the fibre [18][22]. The matrix is likely to have a much greater effect on the crack propagation than suggested. Others sources of error include the constant of $1.46 \mathrm{MNm}^{-3 / 2}$ that was assumed in Equation 1. This constant was again obtained from the testing of bare E-glass fibres that were $12 \mu \mathrm{m}$ in diameter. As can be seen from the table above, there is a range of fibre diameters within the composite material. In order to obtain more accurate values requires the determination of a constant that can be related not only to fibres enclosed in a matrix but also including any effects due to the fibre size. The production of static fatigue data for composite materials should also improve the situation so that the effect of the matrix can be taken into account.

\section{ACKNOWLEDGEMENTS}

The author would like to thank BNR Europe for both their support and the material supplied and the SERC for their support.

\section{REFERENCES}

I SANDBANK,C.P.,"Optical Fibre Communication Systems", John Wiley and Sons (1980) 1.

2 DAVIS,A.J., RADAGE,P., ROWLAND,S.M., WALKER,D.J., presented at Plastics at

Telecommunications VI, London, Sept. (1992).

3 SCANLAN,I.F., Unpublished report No. 412/048/88 STL plc. Harlow, (1988).

4 SENOR,J.,"Optical Fibre Communications", Prentice/Hall International, (1985), 133.

5 BARK,P.R., LAWRENCE,D.O.,"Optical Fibre Transmission", Howard W Sams \& Co,USA (1986) 93

6 FOORD,S.G., "Optical Fibre Communication Systems", John Wiley and Sons, (1980) 70.

7 CHARLES.R.J., J. Appl. Phys. 29 (1958) 1554.

8 WIEDERHORN,S.M., BOLZ,L.H.,J. Amer. Cer. Soc. 53 (1970) 543.

9 METCALFE,A.G., SCHMITZ,G.K., Glass Tech. 13 (1972) 5.

10 METCALFE,A.G., GULDEN,M.E., SCHMITZ,G.K., Glass Tech. 12 (1971) 15.

11 NOBLE,B. HARRIS,S.J., OWEN,M.J., J. Mats. Sci. 18 (1983) 1244.

12 PRICE,J.N., HULL,D., J. Mats. Sci. 18 (1983) 2798.

13 AVESTON,J., SILLWOOD,J.M., J. Mats. Sci. 17 (1982) 3491.

14 MANDELL,J.F., "Developments in Reinforced Plastics 2", Applied Science, (1982) 67.

15 LEVENGOOD,W.C., J. Appl. Phys. 29 (1958) 820.

16 MECHOLSKY,J.J.,FREIMAN,S.W., MOREY,S.M. Cer. Bul. 56 (1977) 1016.

17 MECHOLSKY,J.J.,RICE,R.W.,FREIMAN,S.W., J. Amer. Cer. Soc. 57 (1974) 440.

18 PRICE.J.N. "Fractography and Failure Mechanisms of Polymers and Composites" ed A.C.Roulin-

Molony, Elsevier (1989) 10.

19 TERAO,N., J. Phys. Soc. Japan 8 (1953) 545.

20 JARAS,A.C., NÖRMAN,B.J., SIMMENS,S.C., J. Mats. Sci. 18 (1983) 2459.

21 SIH,G.C., PARIS,P.C. IRWIN.G.R., Int. J. Frac. Mech. 1 (1965) 189.

22 HOGG,P.J., HULL,D., Met. Sci. 14 (1980) 441. 